Економічні науки: збірник наукових праиь Луиького національного технічного університету. - Серія "Регіональна економіка". - Випуск 15 (59). - Редкол.: відп. ред. д.е.н., професор Л.Л. Ковальська. - Луиьк: ІВВ Луиького НТУ, 2018. - 292 с.

УДК 595.771(477.87)

Ерфан В.Й.

к.е.н., доцент кафедри міжнародного бізнесу, менеджменту та логістики, ДВНЗ "Ужгородський національний університет" Газуда C.M.

к.е.н., доцент кафедри менеджменту, туристичного і готельноресторанного бізнесу, Ужгородський торговельно-економічний інститут КНТЕУ

\title{
ПРИРОДНО-ЗАПОВІДНІ АСПЕКТИ РЕГІОНАЛЬНОГО РОЗВИТКУ
}

У статті розглянуто окремі аспекти з охорони та збереження природнозаповідних територій та екомереж регіону. Здійснено порівняльний аналіз показників 3 обсягу капітальних екоінвестицій та поточних витрат, спрямованих на охорону навколишнього природного середовища Закарпаття за період 2016-2000 рр. Обгрунтовано необхідність окреслення і реалізації спеціальних природоохоронних заходів, що сприятиме підвищенню рівня екологічної безпеки, покращенню екологічної ситуації в регіоні та формуванню екологічної свідомості населення краю.

Ключові слова: природно-заповідні території, природоохоронні заходи. 

університету. - Серія "Регіональна економіка". - Випуск 15 (59). - Редкол.: відп. ред. д.е.н., професор Л.Л. Ковальська. - Луцьк: ІВВ Луцького НТУ, 2018. - 292 с.

\section{Erfan V., Gazuda S.}

\section{NATURAL AND RESIDUAL ASPECTS OF REGIONAL DEVELOPMENT}

The article deals with certain aspects of the protection and conservation of nature-protected areas and ecological networks of the region. The comparative analysis of indicators on the volume of capital Eco investment and current expenditures aimed at environmental protection of Zakarpattya for the period of 2016-2000 has been made.

The necessity of defining and realization of special environmental measures, which will promote increase of ecological safety, improvement of ecological situation in the region and formation of ecological consciousness of the population of the region has been grounded.

Key words: nature reserves, nature protection measures.

\section{Ерфан В.И., Газуда С.Н.}

\section{ПРИРОДНО-ЗАПОВЕДНЫЕ АСПЕКТЫ РЕГИОНАЛЬНОГО РАЗВИТИЯ}

В статье рассмотрены отдельные аспекты по охране и сохранению природно-заповедных территорий и экосетей региона. Осуществлен сравнительный анализ показателей по объему капитальных экоинвестиций и текущих расходов, направленных на охрану окружающей природной среды Закарпатья за период 2016-2000 гг. Обоснована необходимость определения и реализации специальных природоохранных мероприятий, что будет способствовать повышению уровня экологической безопасности, улучшению экологической ситуации в регионе и формированию экологического сознания населения края.

Ключевые слова: природно-заповедные территории, природоохранные мероприятия.

\section{Постановка проблеми у загальному вигляді і її зв'язок 3} важливими науковими та практичними завданнями. Унікальність природних екосистем Закарпаття, передусім гірських територіальних, вирізняє його з поміж інших областей України. Привабливість природних екологічних систем регіону 3 їх біологічним і ландшафтним різноманіттям має особливе значення для розвитку туристичної сфери і рекреації. Вони формують єдину територіальну систему, що поєднує ділянки природних ландшафтів, природно-заповідних територій, територій рекреаційного призначення тощо. Формування й 
Економічні науки: збірник наукових праиь Луиького національного технічного університету. - Серія "Регіональна економіка". - Випуск 15 (59). - Редкол.: відп. ред. д.е.н., професор Л.Л. Ковальська. - Луиьк: ІВВ Луиького НТУ, 2018. - 292 с.

охорона екомереж регіону дає можливість відновлення навколишнього природного середовища, збереження біологічного й ландшафтного різноманіття, підвищення рівня природно-ресурсного потенціалу територіальної системи в цілому. Такі території підлягають особливій охороні на законодавчому рівні.

Аналіз останніх досліджень, у яких започатковано вирішення проблеми. Комплексному теоретико-практичному дослідженню проблем забезпечення сталого розвитку природнозаповідного фонду як на національному, так і регіональному рівнях присвятили свої праці вчені-економісти та екологи Ф. Гамор, М. Голубець, Л. Гринів, С. Стойка А. Толстоухов, Ю. Туниця, О. Фурдичко, М. Хилько, О. Царенко та ін. Разом 3 тим, незважаючи на значний науковий доробок з цих питань, дослідженнями не охоплено всього спектра окреслення спеціальних природоохоронних заходів 3 підвищення рівня екологічної безпеки та розширення природно-заповідних територій регіону.

Цілі дослідження. Основна мета дослідження полягає в розгляді природно-заповідних територій, механізмів їх відтворення, аналізі капітальних інвестицій на охорону навколишнього середовища.

Виклад основного матеріалу дослідження 3 повним обгрунтуванням отриманих наукових результатів. До структурних елементів екомережі, як зазначено у Законі України „Про екомережу” [1] відносяться ключові, сполучні, буферні та відновлювані території, де ключові території забезпечують збереження найбільш цінних i типових для окремого регіону компонентів ландшафтного та біорізноманіття. Сполучні території (екокоридори) поєднують між собою ключові території, забезпечують міграцію тварин та обмін генетичного матеріалу. Буферні території забезпечують захист ключових та сполучних територій від зовнішніх впливів. Відновлювані території забезпечують формування просторової цілісності екомережі, для яких мають бути виконані 
Економічні науки: збірник наукових праџь Луцького національного технічного університету. - Серія "Регіональна економіка". - Випуск 15 (59). - Редкол.: відп. ред. д.е.н., професор Л.Л. Ковальська. - Луцьк: ІВВ Луиького НТУ, 2018. - 292 с.

першочергові заходи щодо відтворення первинного природного стану.

Пріоритетним напрямом у сфері охорони навколишнього природного середовища Закарпатської області є створення і розширення заповідних територій. За даними Державного управління охорони навколишнього природного середовища [2] в регіоні знаходиться 450 об'єктів природно-заповідного фонду на площі 177 тис. га, серед яких Карпатський біосферний заповідник, Ужанський національний природний парк, Національні природні парки „Синевир” та „Зачарований край”, регіональний ландшафтний парк „Притисянський”, 19 заказників загальнодержавного значення тощо. До списку Всесвітньої спадщини ЮНЕСКО відноситься українськословацький об'єкт „Букові праліси Карпат", площі якого розташовані на території Карпатського біосферного заповідника та Ужанського національного природного парку. Останній $\epsilon$ складовою частиною трьохстороннього польсько-словацькоукраїнського міжнародного біосферного заповідника „Східні Карпати”. Доцільно відмітити, що в Україні є понад 7 тисяч об'єктів природно-заповідного фонду, що займають 5,4 \% всієї суші країни. Серед регіонів-лідерів, що мають високий „процент заповідності” й Закарпатська область - 13,4\% .

Однак нині в умовах посилення антропогенного впливу на використання природних ресурсів, зокрема застосування методів екстенсивного природокористування відбувається процес деградації природних екосистем, це спричиняє негативні наслідки щодо можливості забезпечення відповідної якості життя в їх межах.

Дослідження підтверджує, що за останні роки в регіоні поступово знижуються суми інвестиційних коштів на охорону навколишнього середовища. Так, у 2016 р. на різні напрями природоохоронної діяльності фактично було витрачено 5,9 млн. грн. капітальних інвестицій (таблиця 1). 
Економічні науки: збірник наукових праџь Луцького національного технічного університету. - Серія "Регіональна економіка". - Випуск 15 (59). - Редкол.: відп. ред. д.е.н., професор Л.Л. Ковальська. - Луцьк: ІВВ Луиького НТУ, 2018. - 292 с.

Таблиця 1

Капітальні екоінвестиції, поточні витрати на охорону навколишнього природного середовища Закарпатської області*

\begin{tabular}{|c|c|c|c|c|c|}
\hline Показники & 2000 & 2005 & 2010 & 2015 & 2016 \\
\hline \multicolumn{6}{|c|}{ Фактично витрачено екоінвестицій, млн. грн. } \\
\hline Всього & 3,2 & 17,2 & 9,9 & 7,8 & 5,9 \\
\hline $\begin{array}{l}\text { y тому числі: } \\
\text { власні кошти }\end{array}$ & 0,4 & 1,9 & 5,0 & 2,2 & 1,3 \\
\hline кошти державного бюджету & 0,2 & 13,3 & - & 7 & - \\
\hline кошти місцевих бюджетів & 2,6 & 2,0 & 4,9 & 1,7 & 13 \\
\hline інші джерела фінансування & 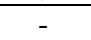 & - & 0,0 & 3,9 & 3,3 \\
\hline \multicolumn{6}{|c|}{ Екоінвестииії за окремими напрямами, (у фактичних цінах, млн. грн.) } \\
\hline Всього & 0,4 & 1,1 & 55,9 & 96,6 & 135,0 \\
\hline $\begin{array}{l}\text { y m.ч. за напрямами: } \\
\text { охорона атмосферного повітря } \\
\text { проблем зміни клімату }\end{array}$ & 0,2 & 0,5 & 0,9 & 0,5 & 0,6 \\
\hline очищення зворотних вод & 0,1 & 0,5 & 34,2 & 40,6 & 47,9 \\
\hline поводження з відходами & 0,1 & 0,1 & 4,4 & 19,7 & 38,7 \\
\hline $\begin{array}{l}\text { захист і реабілітація грунту, підземних } \\
\text { і поверхневих вод }\end{array}$ & 0,0 & 0,0 & 2,2 & 0,8 & 0,0 \\
\hline $\begin{array}{ll}\text { зниження шумового } \\
\text { впливу }\end{array}$ & 0,0 & 0,0 & - & - & - \\
\hline $\begin{array}{l}\text { збереження біорізноманіття } \\
\text { середовища існування }\end{array}$ & 0,0 & 0,0 & 5,2 & 16,3 & 0,0 \\
\hline $\begin{array}{l}\text { інші напрями } \\
\text { діяльності }\end{array}$ & 0,0 & 0,0 & 9,0 & 18,7 & 47,8 \\
\hline
\end{tabular}

*Сформовано за джерелом: [3, с. 210]

Дані статистики свідчать, що фактичні витрати щодо екоінвестицій (таблиця 1) у 2016 р. порівняно з 2000 р. зросли у 1,8 рази. Однак порівняння з 2005 р. засвідчує значне зниження інвестиційних ресурсів у досліджувану сферу, відповідно майже у 3 рази. Навіть порівняння 2016 р. 3 попереднім роком засвідчує певне зниження екоінвестицій (0,8 рази).

Порівняльний аналіз засвідчує, що у структурі капітальних екоінвестицій у 2016 р. переважали кошти 3 інших джерел фінансування (3,3 млн. грн., або 55,9\%), а кошти 3 місцевих 
Економічні науки: збірник наукових праиь Луиького національного технічного університету. - Серія "Регіональна економіка". - Випуск 15 (59). - Редкол.: відп. ред. д.е.н., професор Л.Л. Ковальська. - Луцьк: ІВВ Луиького НТУ, 2018. - 292 с.

бюджетів та власні кошти становили по 1,3 млн. грн., або по $22,0 \%$. За останні роки взагалі відсутні кошти державного бюджету, які б спрямовувалися на охорону навколишнього середовища. За період 2016-2000рр. найбільші інвестиційні ресурси, які фактично витрачалися на охорону навколишнього природного середовища були реалізовані у 2005 р. (17,2 млн. грн.), у 2010 р. - 9,9 млн. грн. і у 2015 p. 7,8 млн. грн.

Найбільші обсяги капітальних інвестицій і поточних витрат на охорону навколишнього природного середовища у 2016 р. було спрямовано на очищення зворотних вод (47,9 млн. грн., або $35,5 \%$ та інші напрями природоохоронної діяльності (47,8 млн. грн., або 35,4\%), а також поводження 3 відходами (38,7 млн. грн., або 28,7 \%), взагалі не виділялося інвестиційних ресурсів і поточних витрат у напрямі зниження шумового i вібраційного впливу та збереження біорізноманіття i середовища існування. В цілому капітальні екоінвестиції та поточні витрати за період 2016-2000 pp. зросли на 134,6 млн. грн., або у 337,5 рази [3, с. 210].

Вирішення проблемних питань стосовно формування підходів у напрямі забезпечення розширеного відтворення та охорони природних ресурсів територіальних економічних систем повинно базуватися на реалізації заходів з раціонального природокористування. Відмічене природокористування, передбачає комплекс науково-технічних, соціальноекономічних, освітніх, культурно-виховних і політико-правових заходів, які пов'язані з успішним задоволенням людських потреб, бережливим ставленням до природних багатств, що у свою чергу, потребує підвищення рівня екологічного мислення працівників усіх сфер діяльності [4, с. 84]. Особливо потрібно закцентувати увагу на формуванні екологічного мислення у процесі господарської діяльності людини i природокористування, зокрема.

Поряд 3 підвищенням рівня суспільної екологічної свідомості населення Закарпаття, доцільним $є$ окреслення i 
Економічні науки: збірник наукових праџь Луцького національного технічного університету. - Серія "Регіональна економіка". - Випуск 15 (59). - Редкол.: відп. ред. д.е.н., професор Л.Л. Ковальська. - Луиьк: ІВВ Луиького НТУ, 2018. - 292 с.

реалізація спеціальних природоохоронних заходів, що в подальшому сприятимуть підвищенню рівня екологічної безпеки та покращенню екологічної ситуації в регіоні, зокрема:

- розроблення дієвої і результативної регіональної екологічної політики;

- охорона і збереження довкілля, передусім 3 метою забезпечення комфортного середовища проживання i зміцнення здоров' я населення краю;

- розширене відтворення природно-заповідних територій, екологічних мереж, збереження біологічного i ландшафтного розмаїття;

- формування екологічно збалансованого розвитку територій та об' єктів ПЗФ;

- окреслення науково-обгрунтованих підходів у сфері екологічного управління;

- інформаційне забезпечення громадськості про екологічну ситуацію в регіоні.

Висновки. Таким чином, в межах регіональної територіальної системи доцільним $є$ формування інноваційної моделі екологічного розвитку, що включатиме можливість розширеного відтворення природно-заповідних територій i об'єктів та екологічних мереж за рахунок експлуатаційних лісів, полонинних екосистем, деградованих земель сільськогосподарського призначення, відпрацьованих кар'єрів тощо. Реалізація виваженого екологічного підходу до розв'язання проблем охорони навколишнього природного середовища сприятиме підвищенню рівня актуалізації i активізації сфери туристичного й рекреаційного господарства.

1. Про екологічну мережу: Закон України від 24.06.2004 № 1864-IV. URL: http://zakon2.rada.gov.ua/laws/show/1864-15

2. Інформаційні дані Державного управління охорони навколишнього природного середовища в Закарпатській області. URL: https://zakarpattya.net.ua/News/71785-Na-Zakarpatti-znakhodytsia-450-obiektivpryrodno-zapovidnoho-fondu-na-ploshchi-177-tys.-ha

3. Статистичний щорічник Закарпаття за 2016 р./ Головне управління статистики у Закарпатській області; за ред. Г.Д. Гриник. Ужгород, 2017. 479 с. 
Економічні науки: збірник наукових праць Луиького національного технічного університету. - Серія "Регіональна економіка". - Випуск 15 (59). - Редкол.: відп. ред. д.е.н., професор Л.Л. Ковальська. - Луцьк: ІВВ Луиького НТУ, 2018. - 292 с.

4. Економічна енциклопедія: [у 3 т.]. - Київ: Видавничий центр «Академія», 2002. / голова редакційної ради: Гаврилишин Б.Д. (голова) [та ін.]. Т. 3 / [відп. редактор Мочерний С.В. та ін.]. - 2002. - 952 с. 